\title{
CODE MIXING AND CODE-SWITCHING ANALYSIS IN THE NOVEL OF HONEST OF FAULT
}

\author{
Fenti Mariska Yohana \\ Universitas Indraprasta PGRI \\ Nurhayati Hasbi \\ Universitas Indraprasta PGRI \\ Jln. Nangka No.58C Tanjung Barat, Jagakarsa, Jakarta Selatan. Indonesia \\ e-mail: fentiyohana113@gmail.com
}

\begin{abstract}
The novel "Honest of Fault" is the novel that bring the readers have to know the code switching and code mixing in the text of it. The author more often shown the code mixing that based on Fasold and Dell in her text. Code switching and code mixing are contained in every scene and the author likes to be switching the text from other languages, likes Betawi language in novel. This research is descriptive qualitative, that use the method of content analysis which is describing the data from sources and the novel itself. From the reduction results by classifying code switching and code mixing, it was found that there was a lot of code mixing in the text of the novel Honest of Fault rather than code switching. Analysis of code switching and code mixing in this novel is often found to be coded because the author deliberately uses foreign phrases that are more familiar and easier to understand by readers than using their mother tongue or Indonesian.
\end{abstract}

Key Words: code switching, code mixing, novel.

Article History: Received: 12/09/2020; Revised: 16/10/2020; Accepted: 25/11/2020; Published: 31/12/2020

How to Cite (MLA 7th): Yohana, Fenti Mariska, and Nurhayati Hasbi. "Code Mixing and Code-Switching Analysis in The Novel of Honest of Fault." Hortatori Jurnal Pendidikan Bahasa dan Sastra Indonesia 4.2 (2020): 116-121. Print/Online. Copyrights Holder: Fenti Mariska Yohana, Nurhayati Hasbi. First Publication: Hortatori Jurnal Pendidikan Bahasa dan Sastra Indonesia (2020).

This work is licensed under a Creative Commons Attribution-ShareAlike 4.0 International License.

\section{Pendahuluan}

Kegiatan apa yang dilakukan orang-orang ketika mereka bersama? Ketika mereka bercerita, bermain, bertanding, atau menyatakan cinta? Mereka berbicara. Kehidupan kita ini tidak lepas dari dunia kata-kata. Kegiatan berkata-kata yang dilakukan ialah menggunakan bahasa. Bahasa adalah media penyampai pesan seseorang terhadap orang lain dimana tutur kata yang dilakukan sampai ke lawan bicara dan mendapat feedback atau umpan balik, sehingga lawan bicara mengerti akan maksud yang disampaikan.

Bahasa merupakan alat komunikasi bagi semua manusia sehingga terjadi komunikasi dengan manusia lainnya. Manusia diciptakan berbeda dengan manusia lainnya, yang membedakannya yaitu akal dan pikiran.

Bahasa sebagai sarana komunikasi berfungsi sebagai pengirim pesan dalam kegiatan komunikasi sehingga makna dapat diterima oleh seseorang serta disampaikan kepada orang lain.

Seperti contoh pada bahasa asing "sorry" daripada "maaf", "No smoking" untuk "dilarang merokok", masyarakat lebih mengenal bahasa tersebut sebagai bentuk komunikasi yang tidak hanya satu bahasa melainkan banyak bahasa. Pengguna bahasa terdiri dari latar belakang yang berbeda, status sosial, pendidikan, pekerjaan, tempat tinggal, serta suku yang berbeda. Perbedaan inilah yang akhirnya menciptakan suatu masyarakat yang mampu berbicara dua bahasa (bilingual) bahkan lebih (multilingual). Minimal mereka menguasai Bahasa Ibu (mother tongue). 
Pengguna bahasa biasanya terdiri dari berbagai jenis orang berbeda latar belakang, status sosial, pendidikan, pekerjaan, tempat tinggal, serta suku yang berbeda. Perbedaan inilah yang akhirnya menciptakan suatu masyarakat yang mampu berbicara dua bahasa (bilingual) bahkan lebih (multilingual). Minimal mereka menguasai Bahasa Ibu (mother tongue). Bahasa itu unik, bahasa itu produktif, bahasa itu universal, bahasa merupakan identitas suatu kelompok sosial. Maka dari itu kemungkinan untuk berbahasa lebih dari satu dapat melatar belakangi keinginan manusia untuk mampu bilingual bahkan multilingual. Inilah yang akan terjadi dalam berkomunikasi, sehingga alih kode dan campur kode terlaksana oleh kebanyakan orang. Alih kode serta campur kode masyarakat multilingual terdapat kesamaan diantaranya dua macam dari satu bahasa pada satu masyarakat. dalam alih kode setiap bahasa atau jenis bahas yang digunakan tersebut masih memiliki fungsi otonomi masing-masing.

Campur kode memiliki kode utama yang disertakan dalam bahasa dimana ini memiliki fungsi keotonomian. Sementara itu kode lain hanyalah serpihan-serpihan, tanpa fungsi sebagai sebuah kode. Misal pada seorang tindak tutur dalam berbahasa Indonesia sering menyisipkan bahasa daerahnya, ia bisa dikatakan telah melakukan campur kode (code mixing).

Sementara itu Chaer dan Leoni (2010: 69) menyebutkan bahwa campur kode sebagai tindakan menggunakan bahasa lebih dari satu atau dua dengan macam yang berbeda dalam tindakan tutur pada satu masyarakat.

Pengertian yang sama juga dikemukakan oleh Sumarsih et. all. (2014: 79) bahwa code mixing is a mixture between two or more languages in which there is a dominant language and inserted with different language to make it sound cool and give appropriate context to the audience or listener. Campur kode adalah pencampuran ragam bahasa ke dalam bahasa yang lebih sering dilakukan dalam tindak tutur dan menyisipkan bahasa yang berbeda untuk membuat kesantaian dan untuk menyesuaikan konteks kepada lawan tutur.

Campur kode menurut Fasold (dalam chaer dan agustina, 2004: 115) yaitu jika seseorang menggunakan satu frasa lain maka akan terjadi campur kode, contoh frasa yang melibatkan hubungan bahasa Hindi dan bahasa Inggris: Vinod: mai to kuhungaa ki yah one of the (saya akan mengatakan bahwa ini adalah salah Best novels of the year is satu novel terbaik tahun ini) Mira: That's right. It is decidedly one of (benar). Penyebab terjadinya campur kode dapat digolongkan menjadi dua, yaitu A. sikap (attitudinal type) 1. Need for synonym latar belakang sikap penutur, maksudnya ialah tindak tutur menggunakan bahasa lain untuk memperhalus maksud tuturan. Contoh: handphone-nya mau di service kapan? Kata "handphone" di sini digunakan untuk memudahkan pengucapan "telepon genggam" dan kata "service" merujuk kepada "perbaikan" yang lebih mudah disebutkan oleh penutur. 2. Social value yaitu penutur sengaja mengambil kata dari bahasa lain dengan mempertimbangkan factor social (penutur cenderung berbahasa asing karena menujukan orang yang berpendidikan). Contoh: Saya sih prefer jadi wanita karier yang juga bisa quality time sama keluarga. 3. Perkembangan dan Perkenalan dengan Budaya Baru Hal ini juga merupakan factor pendukung adanya campur kode oleh tindak tutur, sebab banyak istilah dan strategi penjualan dalam bidang telekomunikasi yang menggunakan bahasa asing, sehingga hal tersebut berdampak pada pemakaian klausa asing oleh penutur yang sebenarnya bukan bahasa asli penutur. Contoh: Mohon dikasih rate ya bu untuk driver kami. B. kebahasaan. Latar belakang kurangnya pengetahuan berbahasa dan bahasa, sehingga ada alasan identifikasi peranan, identifikasi ragam, dan keinginan untuk memaparkan serta menafsirkan. 1. Low frequency of word Terjadi karena kata-kata dalam bahasa asing lebih mudah diingat dan jelas maknanya. Contoh: Kami menyediakan fullset original untuk setiap spare part anda. 2. Pernicious Homonimy yaitu jika tindak tutur menggunakan kata dari bahasanya sendiri maka kata tersebut dapat menimbulkan masalah homonym yaitu makna ambigu. Contoh: Untuk speakernya sudah kami pesan urgent. Kata "speaker" disini adalah pengeras suara. 3. Oversight Yaitu keterbatasan kata-kata yang dimiliki oleh bahasa penutur. Banyaknya istilah dalam bahasa asing sehingga penutur sulit mencari padanannya. Contoh: software, install, flash, dll. 4. End (Purpose and Goal) Ialah ketercapaian atas hasil yang dikehendaki. End (tujuan) untuk membujuk dan meyakinkan sehingga penutur menggunakan campur kode. Contoh: maaf ibu untuk charger tidak dapat di service, tetapi kami bantu replace. Dengan demikian campur kode merupakan peristiwa percampuran bahasa pada situasi atau konteks tertentu. Campur kode terjadi karena adanya hubungan timbal balik antara peranan penutur, bentuk bahasa, dan fungsi bahasa.

Appel (dalam Abdul Chaer dan Agustina, 2004:107) mendefinisikan alih kode itu sebagai "gejala peralihan pemakaian bahasa karena berubahnya situasi." Misal, Nanang dan Ujang, keduanya berasal dari Priangan, lima belas sebelum Ibu Dosen masuk, mereka bercakap-cakap menggunakan bahasa Sunda, 
sesekali berbahasa Indonesia. Lalu masuklah kawannya si Togar. Mereka terlibat percakapan menggunakan bahasa Indonesia. Akan tetapi, Nanang dan Ujang sesekali berbahasa Sunda ketika tidak sedang berbicara dengan Togar. Tak lama kemudian sang Dosen masuk ruangan, mereka diam dan tenang, siap mengikuti perkuliahan. Selanjutnya bu Dosen menjelaskan materi dengan bahasa Indonesia resmi hingga perkuliahan berakhir. Gejala menarik ini dalam studi Sosiolinguistik disebut gejala alih kode (code switching).

Konsep komponen tutur yang disampaikan Poedjosoedarmo, sebenarnya merupakan pengembangan dari konsep yang disampaikan Dell Hymes. Menurutnya terdapat tiga belas komponen yang ada dalam sebuah tuturan itu. ketiga belas komponen itu diantaranya (1) pribadi si penutur atau orang pertama, (2) anggapan penutur terhadap kedudukan social dan relasinya dengan orang yang diajak bicara, (3) kehadiran orang ketiga, (4) maksud dan kehendak si penutur, (5) warna emosi si penutur, (6) nada suasana bicara, (7) pokok pembicaraan, (8) urutan bicara, (9) bentuk wacana, (10) sarana tutur, (11) adegan tutur, (12) lingkungan tutur, (13) norma kebahasaan lainnya ( Rahardi, 2010:40).

Berikut pengertian novel yang disampaikan oleh beberapa ahli, yaitu: 1. Drs. Jakob Sumardjo Novel ialah bentuk pengaplikasian sastra yang sangat populer di dunia, Bentuk sastra ini sangat sering beredar di jagat maya maupun cetak sebab daya komunitasnya yang sangat luas di dalam masyarakat. 2 . Novel Menurut Drs, Rostamaji, M.Pd yaitu karya sastra yang memiliki dua 2 unsur, intrinsik dan ekstrinsik yang keduanya saling berkaitan karena kedua unsur tersebut saling berpengaruh dalam sebuah karya sastra. 3. Menurut Paulus Tukam, S.Pd Novel ialah sebuah karya sastra yang berbentuk prosa serta terkandung unsur-unsur intrinsik di dalamnya 4.Novel Menurut Dr. Nurhadi, sebuah bentuk karya sastra yang di dalamnya terdapat nilai-nilai budaya, sosial, pendidikan, juga moral.

Peneliti tertarik menganalisis novel "Honest of Fault" yang dibuat oleh penulis pemula yaitu Rossie. Hal yang membuat peneliti tertarik yaitu seseorang yang tidak menguasai bahasa yang digunakan oleh masyarakat setempat tentu merasakan kesulitan dalam berkomunikasi, namun mba Rossie mampu mengolah kalimat-kalimat yang di dalam nya terkandung campur kode dan alih kode pada novel karyanya. Inilah yang membuat peneliti tertarik untuk menganalisis novel karya Rossie dimana ia adalah penulis pemula namun mampu bermain campur kode dan alih kode.

Penelitian yang relevan tentang pemakaian campur kode dan alih kode yaitu artikel Siti Rohmani dimana beliau meneliti tentang analisis alih kode campur kode pada novel Negeri 5 Menara karya Ahmad Fuadi, dimana penulis menitikberatkan mengenai bentuk alih kode dan campur kode, faktor penyebab alih kode dan campur kode terlaksana, fungsi alih kode campur kode pada novel, serta faktor pendorong terjadinya alih kode campur kode.

Berdasarkan penelitian relevan tersebut, peneliti tertarik menganalisis novel "Honest of Fault" ini, karena dalam tulisannya banyak peneliti temukan kalimat yang terdapat unsur-unsur penyebab terjadinya alih kode dan campur kode. Unsur yang ada pada teori yang disampaikan oleh Fasold mengenai campur kode serta pengembangan dari konsep yang disampaikan Dell Hymes mengenai alih kode menjadi tujuan peneliti mengulik tulisan sang penulis ini.

Dalam hal ini peran penguasaan bahasa sangat diperlukan dalam menulis novel, dan penulis mampu akan hal itu.

Hal yang melatarbelakangi peneliti untuk meneliti tulisan beliau ialah selain novel yang beliau tulis banyak terdapat alih kode dan campur kode pada ceritanya, beliau juga merupakan seorang karyawan swasta yang bukan merupakan penulis novel kebanyakan yang memang concern dalam menulis novel. Rossie penulis pemula namun pada novel yang dibuatnya sebanyak 303 halaman sering peneliti temukan alih kode dan campur kode berdasar unsur yang dikemukakan oleh ahli.

\section{Metode}

Metode yang digunakan dalam penelitian ini adalah metode kualitatif dengan teknik analisis isi (content analysis). Penelitian ini adalah penelitian deskriptif, yakni mendeskripsikan data berupa mendeskripsikan fakta-fakta yang kemudian disusul dengan analisis. Dengan menggunakan metode deskriptif analisis, peneliti bermaksud mengetahui struktur masing novel, dengan mengumpulkan data, menyusun, mengklasifikasikan, lalu menginterpretasikan.

Sumber data berasal dari hasil reduksi seluruh teks yang ada pada novel "Honest of Fault" serta menelaah buku sumber dari berbagai literatur mengenai alih kode dan campur kode dengan menetapkan 
teori Fasold mengenai campur kode serta pengembangan dari konsep yang disampaikan Dell Hymes mengenai alih kode menjadi metode yang digunakan peneliti untuk mengulik novel.

Teknik mengumpulkan data dalam penelitian ini yaitu berupa studi pustaka, yaitu menelaah buku dari berbagai sumber maupun literatur yang berkaitan dengan penelitian. Dalam penelitian ini peneliti menggunakan salah satu cabang kajian Sosiolinguistik yaitu Alih Kode dan Campur Kode. Novel Honest of Fault diolah dengan menggunakan metode deskriptif analisis dimana peneliti mengklasifikasikan urutan kerja yang diantaranya;1. Penulis membaca novel yang dibuat oleh Rosyidah berjudul Honest of Fault. 2. Penulis memperhatikan kata demi kata sehingga terdapatnya alih kode atau campur kode di dalam percakapan atau teks novel tersebut. 3. Penulis melakukan analisis secara deskriptif, kalimat atau kata-kata manakah yang termasuk alih kode, dan manakah yang termasuk campur kode. 4. Menjelaskan dengan rinci kalimat-kalimat yang termasuk alih kode dan kalimat-kalimat yang termasuk campur kode. 5. Merumuskan dan membuat simpulan.

\section{Hasil dan Diskusi}

Hasil dan diskusi berdasarkan analisis yang telah dilakukan, temuan pokok terkait dengan data campur kode dapat dilihat pada tabel berikut.

Tabel 1. Hasil Campur Kode dan Alih Kode

\begin{tabular}{|c|c|c|c|}
\hline No & Kalimat & Campur Kode & Alih Kode \\
\hline 1 & $\begin{array}{l}\text { Itu kenapa kalo di kampus aku dapat panggilan si "Pretty } \\
\text { Boy", hehehe... aku sih hanya bisa tersenyum setiap kali } \\
\text { seantero kampus memanggilku dengan sebutan itu. }\end{array}$ & $\begin{array}{l}\text { Kalimat ini termasuk campur kode } \\
\text { karena penggunaan satuan bahasa } \\
\text { dari satu bahasa ke bahasa lain } \\
\text { yaitu bahasa Indonesia ke bahasa } \\
\text { Inggris "Pretty boy." }\end{array}$ & \\
\hline 2 & $\begin{array}{l}\text { Bosen nungguin mobilku diservice, aku jalan - jalan aja } \\
\text { dulu, eh... nggak sengaja ngeliat kamu yang kayaknya lagi } \\
\text { kelelahan banget. }\end{array}$ & $\begin{array}{l}\text { Kalimat ini termasuk campur kode } \\
\text { karena penggunaan satuan bahasa } \\
\text { dari satu bahasa ke bahasa lain } \\
\text { yaitu bahasa Indonesia ke bahasa } \\
\text { Inggris "diservice" }\end{array}$ & \\
\hline 3 & $\begin{array}{l}\text { Kami pun pergi ke bengkel. Alangkah terkagumnya aku } \\
\text { melihat mobilnya, sebuah sedan sport berwarna merah } \\
\text { menyala yang mungkin harganya bisa miliaran rupiah. }\end{array}$ & $\begin{array}{l}\text { 1. Kalimat ini termasuk } \\
\text { campur kode karena Pernicious } \\
\text { homonymy Maksudnya adalah jika } \\
\text { penutur menggunakan kata dari } \\
\text { bahasanya sendiri maka kata } \\
\text { tersebut dapat menimbulkan } \\
\text { masalah homonym yaitu makna } \\
\text { ambigu. }\end{array}$ & \\
\hline 4 & $\begin{array}{l}\text { "Tempatku di Flat lantai paling atas.." ucap mitha sambil } \\
\text { memencet tombol lift. }\end{array}$ & $\begin{array}{l}\text { Kalimat ini termasuk campur kode } \\
\text { karena jika penutur menggunakan } \\
\text { kata dari bahasanya sendiri maka } \\
\text { kata tersebut dapat menimbulkan } \\
\text { masalah homonym yaitu makna } \\
\text { ambigu. }\end{array}$ & \\
\hline 5 & $\begin{array}{l}\text { "Kenapa gak bilang? Kan ada handphone ku, bisa kamu } \\
\text { pake untuk nelpon ibumu, ngasih kabar ke dia kalo kamu } \\
\text { baik - baik aja" lanjut Mitha. }\end{array}$ & $\begin{array}{l}\text { 2. Kalimat ini termasuk } \\
\text { campur kode karena Low frequency } \\
\text { of word } \\
\text { Terjadi karena kata-kata dalam } \\
\text { bahasa asing lebih mudah diingat } \\
\text { dan lebih stabil maknanya. }\end{array}$ & \\
\hline 6 & $\begin{array}{l}\text { "By the way, lo temannya Mitha dari mana? Kok kayak nya } \\
\text { gue belum pernah liat lo?" tanya Mikha penasaran. }\end{array}$ & $\begin{array}{l}\text { Kalimat ini termasuk campur kode } \\
\text { karena Social value yaitu penutur } \\
\text { sengaja mengambil kata dari } \\
\text { bahasa lain } \\
\text { mempertimbangkan factor sosial } \\
\text { karena penutur cenderung } \\
\text { berbahasa asing juga menujukan } \\
\text { orang yang berpendidikan. }\end{array}$ & \\
\hline 7 & "Yap, just like you see!" jawab ku singkat. & & $\begin{array}{l}\text { Kalimat ini termasuk alih kode } \\
\text { karena faktor komponen bahasa } \\
\text { yang bermacam-macam. }\end{array}$ \\
\hline 8 & $\begin{array}{l}\text { "Trus kenapa kamu ngeliatin aku sampai segitunya ?" lanjut } \\
\text { Mitha penasaran. } \\
\text { "Nggak kenapa - napa. Aku cuma speechless aja denger } \\
\text { kata - kata kamu tadi. }\end{array}$ & $\begin{array}{l}\text { Kalimat ini termasuk campur kode } \\
\text { karena Social value yaitu penutur } \\
\text { sengaja mengambil } \\
\text { bahasa } \\
\text { bata dari }\end{array}$ & \\
\hline
\end{tabular}




\begin{tabular}{|c|c|c|c|}
\hline & & $\begin{array}{l}\text { mempertimbangkan factor social } \\
\text { (penutur cenderung berbahasa asing } \\
\text { karena menujukan orang yang } \\
\text { berpendidikan). }\end{array}$ & \\
\hline 9 & $\begin{array}{l}\text { "Ayahku adalah orang yang temperamental, emosi nya } \\
\text { mudah sekali tersulut kalo ada seseorang yang tidak } \\
\text { mendengarkan kata - katanya, even anak dan istrinya sendiri } \\
\text { pasti jadi pelampiasan amarahnya. }\end{array}$ & $\begin{array}{l}\text { 3. Kalimat ini termasuk } \\
\text { campur kode karena Low frequency } \\
\text { of word } \\
\text { Terjadi karena kata-kata dalam } \\
\text { bahasa asing lebih mudah diingat } \\
\text { dan lebih stabil maknanya. }\end{array}$ & \\
\hline 10 & $\begin{array}{l}\text { Aku hanya menggeleng - gelengkan kepalaku "Aku takut, } \\
\text { Mit, aku takut, meski penampilanku kadang urakan dan } \\
\text { slengean kaya preman tapi aku gak pernah memukul orang } \\
\text { sampai berdarah - darah seperti ayah begitu“. }\end{array}$ & $\begin{array}{l}\text { Kalimat ini termasuk campur kode } \\
\text { karena kata yang digunakan } \\
\text { penutur dirasa cukup tepat dalam } \\
\text { menggambarkan situasi. }\end{array}$ & \\
\hline
\end{tabular}

Dari hasil reduksi dengan mengklasifikasikan alih kode serta campur kode ini, didapatkan banyak campur kode dalam teks novel Honest of Fault ketimbang alih kode. Analisis alih kode dan campur kode pada novel tersebut sering didapati campur kode karena penulis sengaja menggunakan frase asing yang lebih diketahui dan mudah dipahami pembaca dibanding menggunakan bahasa ibu atau bahasa Indonesia.

Penerapan yang dapat dilihat langsung pada kalimat-kalimat yang terdapat dalam novel Honest of Fault yaitu banyak terdapat kalimat campur kode karena penulis memiliki pemahaman mengenai perkembangan dan perkenalan dengan Budaya Baru.

Berdasarkan pemahaman campur kode dan alih kode pada novel Honest of Fault di sini penulis sangat menggambarkan penutur sebagai pemeran utamanya. Maka dari itu banyak terjadi alih kode dan campur kode dalam teks novel Honest of Fault.

\section{Simpulan}

Alih kode dan campur kode yang terdapat dalam teks novel Honest of Fault sangat terlihat hampir di tiap scene yang diceritakan penulis. Penulis pun suka menyisipkan kata-kata dari bahasa lain seperti bahasa Betawi pada teks novel.

Selain itu penulis pun melakukan alih kode pada kalimat yang digunakannya dalam novel. Novel yang ditulis merupakan bentuk karya sastra yang di dalamnya itu terdapat nilai-nilai budaya, social.

Maka dari itu si penulis memiliki pemahaman campur kode dan alih kode pada novel Honest of Fault, di sini terlihat penulis sangat menggambarkan penutur sebagai pemeran utamanya. Maka dari itu banyak terjadi alih kode dan campur kode dalam teks novel Honest of Fault.

\section{Ucapan Terima Kasih}

Peneliti mengucapkan terima kasih pada semua pihak yang mendukung penelitian ini baik secara moril maupun materiel. Serta rekan dosen sejawat yang banyak memberikan masukan dan saran. Terima kasih pula kepada tim editor jurnal Hortatori yang telah memberikan arahan untuk memublikasikan hasil penelitian ini.

\section{Daftar Rujukan}

Abdullah, Alek, and H. P. Achmad. Linguistik umum. Jakarta: Erlangga, 2012.

Alwasilah, Adeng Chaedar. Linguistik: Suatu Pengantar. Penerbit Angkasa, 2011.

Asnawi. "Hakikat Campur Kode". http://as-nawi.blogspot.com. 2011. Oktober 2020

Azhar, Iqbal Nurul. Sosiolinguistik Teori dan Praktik. Surabaya: Lima-lima Jaya, 2011.

Chaer, Abdul, and Leoni Agustina. Sosiolinguistik: Perkenalan Awal. Jakarta: PT Rineka Cipta, 2004.

Herman. "Alih Kode Bahasa dalam Interaksi Jual Beli di Pasar Inpres Manonda Kota Palu". Media.Neliti.Com/Media/Publications/74560-Id-Alih-Kode-Bahasa-Dalam-Interaksi-JualBe.Pdf. November 2020.

Ibeng, Parta. "Pengertian Novel, Ciri, Struktur, Jenis, Unsur Intrinsik dan Ekstrinsik". PENDIDIKAN.CO.ID. 13 November 2020. Oktober 2020.

Jendra, M. The Study of Societies' Language. Yogyakarta: Graha Ilmu, 2010.

Mahsun, M. S. Metode Penelitian Bahasa. PT Raja Grafindo Persada, 2005. 
Muhammad. Metode Penelitian Bahasa. Yogyakarta: Ar-Ruzz Media, 2014.

Pamunkas F.X. Dwi. "Analisis Alih Kode dan Campur Kode dalam Pembelajaran BIPA di Lembaga Bahasa Universitas Sanata Dharma Yogyakarta”. repository.usd.ac.id. 2018. November 2020.

Rahardi, Kunjana, and Jamaludin, A. Kajian Sosiolinguistik (Ihwal Kode dan Alih Kode. Bogor: Ghalia Indonesia, 2015.

Rahardi, Kunjana. Kajian Sosiolinguistik. Bogor: Ghalia Indonesia, 2010.

Rohmani, Siti, Amir Fuady, and Atikah Anindyarini. "Analisis Alih Kode dan Campur Kode pada Novel Negeri 5 Menara Karya Ahmad Fuadi". https://Media.Neliti.Com/Media/Publications/54301-Id-None.Pdf. 2013. November 2020. 